\title{
Developing Language Competency of University Teachers to Implement Content and Language Integrated Learning (CLIL) in a Regional University: Challenges and Prospects
}

\author{
Natalia S. Godzhaeva and Timur A. Logunov* \\ Kemerovo State University \\ 6 Krasnaya Str., Kemerovo, 650043, Russia
}

Received 26.08.2015, received in revised form 06.09.2015, accepted 10.10.2015

A fundamental flaw in FL training is the fact that it is based either mostly on the principles of General Language, thus leaving graduates unprepared for their occupational-specific language needs, or predominantly concentrated on a Language for Special Purposes field, thus leaving general language competences basically underdeveloped. Prospects of implementing integrated educational approaches in the contemporary conditions of a peripheral university are basically determined by the lack of resources (mostly human).

Our primary concern is developing available teaching staff, their preparedness to upgrade their professional level and possibilities for further education. We conducted a study among teachers and students, which demonstrated higher motivation of the former to improve language skills, however both groups were rather pessimistic with regard to CLIL implementation in the university.

The paper summarizes challenges of the current situation: (1) system-related problems: lack of mutual preparedness of all learning-teaching process participants for interaction; (2) staffrelated problems: extremely few FL teachers with a second degree and very small number of content teachers with sufficient level of FL competence. (3) curriculum-related problems: current curricula were not basically designed for bilingual training. To improve the situation adaptation of education programmes is required for wider coordination between FL-courses and content courses, introducing more content component in FL courses: including studying particular modules, preparing course projects or parts of graduation projects, linguistic support in the form of language courses in specific areas of study. The particular tasks for FL-teachers in course coordination include identifying and developing concrete linguistic competences.

Keywords: Content and language integrated learning; bilingual education; teacher collaboration.

The article is written with the financial support of the European Commission within the Tempus IV programme (Project "Lifelong Language Learning University Centre Network for New Career Opportunities and Personal Development (UNICO)”, № 544283-TEMPUS-1-2013-1-ES-TEMPUSJPHES).

DOI: 10.17516/1997-1370-2015-8-11-2299-2306.

Research area: pedagogy.

(C) Siberian Federal University. All rights reserved

* Corresponding author E-mail address: lexis@kemsu.ru 


\section{Introduction}

Contemporary labour market is highly globalized and to increase students and university graduates' competitiveness it is essential that they receive quality training to acquire necessary knowledge and skills, including speaking a foreign language, primarily, English. The lack of technical, material and human resources in non-linguistic departments of regional universities determines the particularities of CLIL implementation. In this paper we analyze the conditions and attitudes to developing bilingual programmes in a regional higher education institution.

Expert recognize bilingual programmes as an effective way to motivate students to develop communicative skills in a foreign language (FL) that are absolutely essential for increasing graduates' mobility and flexibility in today's job market. Additionally, studying subjects in a FL facilitates academic mobility: students receiving academic training through English have greater opportunities to continue their studies in other European and non-European universities (Pavon, Gaustad, 2013).

Although it is considered to be a relatively new method of teaching on the level of higher education, integrated approach has been widely implemented in the European universities. The reasons for such educational developments can be summarized as follows: attracting more national and international students; improving the position of the university in the national and international educational market; new opportunities for students in the labour market; creating and maintaining educational, economic and cultural partnerships with other countries; prospects of collaborative work among universities in various fields.

As D. Lasagabaster has rightly noted, numerous benefits of this type of education include "improved motivation, increased knowledge of specific terminology, the strengthening of intercultural communicative competence and as a result, improvement in overall target language proficiency" (Lasagabaster, 2008).

\section{Theoretical framework}

The organization of the integration between content and language subjects is a relatively new development in the field of English Language Teaching. The term CLIL itself was coined in 1994 by David Marsh and Anne Maljers to refer to a methodology similar to but distinct from language immersion and content-based instruction. It is an approach for learning content through an additional language (foreign or second), thus teaching both the subject and the language.

This kind of approach has been identified as a very important one by the European Commission because: "It can provide effective opportunities for pupils to use their new language skills now, rather than learn them now for use later" (Marsh, 2008).

In CLIL, the academic content of the nonlinguistic subjects and the foreign language are learnt simultaneously, which calls for curricular integration of the learning of both of them. It should be stressed that "CLIL does not promote the learning of academic content in a FL but through the FL" (Pavon et al., 2014).

Baetens Beardsmore specifies that "one of the significant characteristics of CLIL is the establishment of coordinated work between the content teacher and the FL teacher, by which FL teachers provide linguistic support for students, necessary to understand and assimilate academic content" (Baetens Beardsmore, 2009).

However, the organization of the integration between content and language subjects is not an easy attempt. Experts argue that it requires a complicated coordination pattern: "a potentially suitable option to organize Content and Language 
subjects in a counterbalanced way could be established by covering three different kinds of coordination: between the FL teacher and the content teachers, between the different language teachers (L1, L2 ...) and between the different content teachers" (Pavon et al., 2014).

\section{Statement of the problem}

Obviously, the problem of limited resources (human, material, technical and others) in a modern non-language training higher educational institution determines peculiarities of CLIL approach in this aspect.

In this paper we attempt at investigating opportunities, challenges and prospects of implementing bilingual educational approaches in the contemporary conditions of a peripheral University. Particularly, we are to study the available resources and determine possible ways of its developing to implement CLIL approach in the Faculty of History and International Relations of Kemerovo State University.

One of the meaningful contradictions leading to a fundamental flaw in FL training is the fact that English language training of students is based mostly either on the principles of General English, thus leaving graduates unprepared for their occupational-specific language needs, or predominantly concentrated on the English for Special Purposes field thus leaving general language competences basically underdeveloped or unattended. As a result, in combination with a peculiar situation in the modern Russian labour market when many university leavers choose their job in a professionally unrelated spheres graduates are often not prepared to meet the occupational specific language needs they may face at work. Moreover, finding a great gap between the English they were taught and the one they need in their work, young professionals start feeling discouraged about their university language training.
Therefore, our primary concern is developing available human resources in question, the teaching staff, and their preparedness to upgrade their professional level, motivation and possibilities for further education.

To identify feelings and attitudes of teaching staff with regard to CLIL implementation in the university we conducted a study among two groups of university teachers and junior students.

Data in this study were collected by means of a questionnaire done by 23 learners attending a specifically designed course of Academic English (teachers of various faculties) and 13 teachers of Faculty of History and International Relations (FH\&IR) who did not attend the course.

The questionnaire consisted of 16 questions, falling into two main categories: a) general information about the participants, current proficiency level and language qualification; b) overall need for Content and Language Integrated Learning, its benefits, and conditions for introducing Content and Language Integrated Learning in Kemerovo State University.

This study revealed that both groups, the English course learners and teachers of FH\&IR, feel that Content and Language Integrated Learning should be taught. Unfortunately, many content teachers are unsure about the way they should perform in the CLIL/bilingual class, first, because they are not aware of the methodological changes required in these contexts and second, because of their lack of a high level of competence in the language (Pavon, Rubio, 2010).

Both the content teachers and the English course learners emphasize that they should have sufficient linguistic competence to be able to disseminate academic content in a foreign language and a specific English course should be designed for their occupational needs.

The results of their responses are summarized in Table 1. 
Table 1

\begin{tabular}{|c|c|c|}
\hline Category & Frequency & Percentage \\
\hline Overall need for English & 34 & $94 \%$ \\
\hline Language qualification & $\begin{array}{l}22 \text { - intermediate } \\
7 \text { - pre-intermediate }\end{array}$ & $\begin{array}{ll}61 \% \\
19 \%\end{array}$ \\
\hline English language needs & $\begin{array}{l}24-\text { for occupational purposes. } \\
8 \text { - for entertainment } \\
8 \text { - for personal English needs }\end{array}$ & $\begin{array}{l}67 \% \\
22 \% \\
22 \%\end{array}$ \\
\hline $\begin{array}{l}\text { Frequency of using } \\
\text { English }\end{array}$ & $\begin{array}{l}11-\text { seldom } \\
7-\text { often } \\
5 \text { - constantly }\end{array}$ & $\begin{array}{l}30.5 \% \\
19 \% \\
14 \%\end{array}$ \\
\hline Overall need for CLIL & $\begin{array}{l}30-\text { - "for" } \\
4-\text { - "against" }\end{array}$ & $\begin{array}{l}83 \% \\
11 \%\end{array}$ \\
\hline The benefits of CLIL & $\begin{array}{l}15 \text { - developing international partnership with other } \\
\text { universities } \\
7 \text { - raising the university rating }\end{array}$ & $\begin{array}{l}42 \% \\
22 \%\end{array}$ \\
\hline $\begin{array}{l}\text { Conditions for } \\
\text { introducing CLIL in } \\
\text { Kemerovo State } \\
\text { University } \\
\end{array}$ & $\begin{array}{l}19 \text { - the necessity of an English course } \\
4 \text { - the necessity of developing postgraduate } \\
\text { programs with international partners } \\
4 \text { - the necessity of invitation of foreign scientists }\end{array}$ & $\begin{array}{l}52 \% \\
11 \% \\
11 \% \\
\end{array}$ \\
\hline Ability of teaching in CLIL format & $\begin{array}{l}17-" \text { "no" } \\
5-\text { - "yes" }\end{array}$ & $\begin{array}{l}47 \% \\
14 \%\end{array}$ \\
\hline
\end{tabular}

\section{Discussion}

Having analyzed the data collected from responses of the participants, we identified that the vast majority of respondents (94\%) need English, mostly for occupational purposes (67\%). Interestingly, although the responses of the English course learners and content teachers were largely similar, the English course learners use English more frequent, which demonstrate their higher level of motivation.

However, the participants stressed mostly abstract benefits of the CLIL implementation, such as developing international partnership with other universities (42\%) and raising the university rating (22\%) which may show they do not definitely see particular practical benefits of CLIL approach. The responses in the questionnaires showed that $30 \%$ of teachers are in favor of Content and Language Integrated Learning. According to the responses, both groups of the participating teachers claimed that their linguistic proficiency levels were not adequate for them to teach in English and $52 \%$ stated that they would prefer to improve their language level for this purpose.

In order to gain a broader picture of the occupational English language needs of the students this study surveyed 20 students studying at History Faculty of Kemerovo State University.

The vast majority of the students reported needing English, but solely for personal purposes such as watch foreign TV series or films, using the computer programs, developing their personalities and communicating with foreigners.

Most of the students stated their linguistic proficiency levels were not adequate for implementing CLIL in Kemerovo State University. The responses revealed that most of the students claim a need to improve their English language levels in order to be able to study successfully. 
As a result, the students did not welcome the idea that some historical courses will be taught in non-traditional ways in English.

Needless to say, the identified needs of content teachers in Kemerovo State University and the English course learners may be considered as a basis for future CLIL program to be designed for the students who will be using English to perform their jobs effectively. Through this study it was determined that the participants are in need of being able to use English for different purposes.

To sum up the issue of motivation, we can conclude that many respondents demonstrated some level of motivation as a realization of need for improving the situation, since this kind of motivation to develop one's professional potential is created on the basis of contradiction between the needs and lack of resources and opportunities to satisfy them. In contrast to the case with students, conscious motivation in the content teachers developed as a result of acquiring professional experience, revealing some lack of competences created in the process of studying undergraduate and postgraduate programmes.

In this paper we stress the importance of developing and implementing bilingual programmes at the university level. However, the challenges that our current situation poses are many so we can consider at least three aspects of the problem:

1) System-related problems: need for mutual preparedness of all participants of learning-teaching process for interaction, changing approach to professional training process, teaching methods, curriculum design and some regulatory documents, changes in teacher work load as a result and so on. This category of problems seems to be the most complicated to be solved in near future. In the contemporary conditions, changing regulatory component in this way is considered very unlikely, however, we can make progress in changing attitudes of individual participants of the process: increasing their motivation, determining and expressing their needs, interests, etc.).

2) Staff-related problems: extremely few FL teachers have second degree and very small numbers of content teachers possess sufficient level of foreign language competence, not to mention the fact that university teachers have to master different types of competences: a general language proficiency and competence in various special communication skills. The only way to solve this problem is teaching teachers, including further training programmes, developing their professional potential, which in turn poses new problems, in particular, university teachers should be given more time off work to improve their linguistic competence.

3) Curriculum-oriented problems (educational programme content): our current curricula were not designed basically for bilingual training, thus new generation education programmes should be more adapted in this respect in the way of wider coordination between FL courses and content courses, introducing more content component in FL courses: including studying particular modules, topics, preparing course projects or parts of graduation projects (e.g., the one related to literature review), linguistic support in the form of language courses in specific areas of study, and a flexible and gradual introduction of the additional language in the classrooms.

Working in the direction of solving the problems of the $3^{\text {rd }}$ group seems to be the most realistic way to improve the situation in the near future. Thus, considering the key role of interaction between various participants of training process as a way of increasing teaching quality we find FL teacher Content teacher to be the most essential aspect 
of this interaction. The particular tasks for FL teachers in this area of course coordination include determining the concrete components of linguistic competences proper (necessary language structures and vocabulary), i.e. developing the minimum necessary foundation for implementation of CLIL courses (or at least for implementing their components/elements on the current stage).

While interacting with learners of the aforementioned special course for non-FL teachers we tried to determine the language needs of learners clearly. Being experienced university teachers and researchers they basically possess a good command of professional vocabulary, while feeling almost helpless about language means of connecting words to produce more complex structures (participial, infinitive structures, clauses), demonstrating considerable lack of general academic vocabulary (mostly, verbs) and being in need of simple ways to maintain professional communication (e.g. questionanswer exchange).

Furthermore, another identified challenge was content teachers' inability to objectively evaluate levels of their skills and, as a result, their wrong choice of educational programme to develop these skills. While this problem can be relatively easily solved through procedures of placement assessment and interviewing performed by trained FL-teachers of the same educational institution, this leads to another challenge for designing training programmes for the language courses offered to content teachers. Time, human and technical resources being rather limited, it is rather unrealistic to form groups of learners with comparatively similar starting level of skills. Thus, instructors of such courses face the problem of considerable diversity of needs, demands, even approaches within one group of learners. At this stage, the only solution of this problem may be more active implementation of individual approach by organizing extracurricular activities as well as extra in-class activities for individual learners. It goes without saying that it can become possible only through application of modern ICT techniques (remote training, online training, extra computer-based practice). This in turn requires range of available teaching aids and more time for diversification of both training programme designing and teacher $\square \square$ learner communication.

\section{Conclusion}

In the globalized world, it is essential that graduates receive adequate training to master English; an objective that requires designing an appropriate and, above all, effective educational model. One of the ways to achieve this aim is to implement a programme to teach subjects through an additional language.

In this study we determined the specific measures to be taken in implementing the programme: training teachers in language and bilingual methodology, coordinating the teaching of academic content and language needs, and improving students' second language competency. To achieve the desired results, bilingual programmes need to involve dedicated teachers and interested students, and they need to be supported by university administrators and programme leaders that understand the management and pedagogical principles involved.

\section{References}

Baetens Beardsmore, H. Language Promotion by European Supra-national Institutions. Bilingual Education in the 21 st Century: a Global Perspective. Hoboken, NJ, Wiley-Blackwell, 2009, p. 197217. 
Lasagabaster, D. (2008) Foreign language competence in content and language integrated courses. The Open Applied Linguistics Journal, 1, 31-42.

Marsh, D. Language Awareness and CLIL. Encyclopedia of language and education. Knowledge about language. New York, Springer Science and Business Media LLC, 2008, p. 233-246.

Pavón, V. \& Gaustad, M. (2013). Designing Bilingual Programmes for Higher Education in Spain. Organisational, Curricular and Methodological Decisions. International CLIL Research Journal, 2 (1), 81-94.

Pavón, V. \& Rubio, F. (2010) Teachers' Concerns about the Introduction of CLIL Programmes. Porta Linguarum, 14, 45-58.

Pavón, V., Javier Ávila López, Arturo Gallego Segador \& Roberto Espejo M. (2014). Strategic and organizational considerations in planning content and language integrated learning: a study on the coordination between content and language teachers. International Journal of Bilingual Education and Bilingualism, doi: 10.1080/13670050.2014.909774

\section{Развитие лингвистической компетентности}

\section{преподавателей вуза}

в целях реализации предметно-языкового

интегрированного обучения

в региональном университете:

проблемы и перспективы

Н.С. Годжаева, Т.А. Логунов

Кемеровский государственный университет

Россия, 650043, Кемерово, ул. Красная, 6

Фундаментальным недостатком преподавания иностранных языков является то, что подготовка ведется либо на материале только общелитературного языка, при этом выпускники вуза остаются не готовыми к иноязычному общению в рамках их профессии, либо обучение языку ограничено преимущественно языком для специальных иелей. Таким образом, остаются неразвитыми общелингвистические компетенщии, в частности готовность $\kappa$ иноязычной коммуникации. Перспективы реализачии комплексных образовательных подходов в современных условиях периферийного вуза в основном определяются недостатком ресурсов (главным образом кадровых). Следовательно, основной задачей представляется развитие компетентности научно-педагогических кадров, их готовности повышать свой профессиональный уровень. Проведенное среди студентов и преподавателей исследование продемонстрировало высокий уровень мотивачии (особенно последних) улучшить языковые навыки, однако обе группы высказались довольно пессимистично в отночении реализации CLIL в университете.

B статье рассматриваются основные препятствия для внедрения интегрированного обучения: (1) системные проблемы: отсутствие взаимной готовности всех участников образовательного процесса к взаимодействию; (2) кадровые проблемы: чрезвычайно малое количество преподавателей иностранных языков, имеющих второе спещиильное образование, 
и очень небольшое количество преподавателей неязыковых дисциплин с достаточным уровнем иноязычной компетенции; (3) проблемы учебного плана: текущие программы в основном не предназначены для двуязычного обучения. Для изменения ситуации требуется адаптация образовательных программ для более иирокого взаимодействия между языковыми курсами и профессиональными дисциплинами в плане более широкого внедрения элементов профессиональных дисциплин в курс иностранного языка: в том числе изучение конкретных модулей, подготовка курсовых проектов или части дипломных проектов на языке, лингвистическую поддержку в форме дополнительных программ обучения иностранному языку в конкретных областях исследования. Задачей преподавателей иностранного языка по координации введения двуязычных программ является, в частности, определение и развитие конкретных языковых компетенций.

Ключевые слова: предметно-языковое интегрированное обучение, двуязычное образование, сотрудничество и взаимодействие преподавателей.

Статья написана при финансовой поддержке гранта программы ТЕМПУС IV Европейского Союза (проект «Создание сети университетских языковых центров для профессионального и личностного развития человека в рамках парадигмы «образование в течение всей жизни», № 544283-TEMPUS-1-2013-1-ES-TEMPUS-JPHES).

Научная специальность: 13.00.00 - педагогические науки. 